\title{
The Value of Internet Research to Danish Council Reporters
}

\author{
Kirsten SPARRE
}

\begin{abstract}
This article presents the findings from qualitative interviews with nine Danish council reporters on how they use the Internet for research on council affairs. Through qualitative interviews, the article aims to qualify and expand findings from survey research on journalists' use of the Internet for research and asks how much value journalists add to information found on the Internet and how important Internet research is compared to other types of research. The journalists interviewed found that the council website was useful as a provider of factual information about the council and a searchable archive of council affairs. Most importantly, the website expands the opportunities for monitoring council affairs. Journalists also found that access to Internet-based information on websites outside the council has improved the quality of their products. Generally, council reporters add context, opinions, and democratic control to information found on the Internet and do not see the Internet as a competitor for audience attention.
\end{abstract}

Keywords: Internet, journalism, research, council reporting, Denmark, working methods

\section{Introduction}

Use of the Internet and e-mail for research purposes is universal amongst journalists in the rich part of the world. Survey after survey based on questionnaires show that journalists find the Internet including e-mail particularly useful for monitoring particular beats, identifying and contacting sources, getting story ideas and collating information. ${ }^{1}$

The surveys document that journalists have found innumerable ways to integrate the Internet and e-mail in their daily work routines particularly during the research phase. Unfortunately, the surveys do not situate the use of the Internet in a wider context that could help us understand how important the Internet has become overall for the journalistic research process. Instead survey based research on journalists' use of the Internet draws a picture of a rather unclear and one-dimensional research process which does not take into account that journalists can chose between and combine different research methods including the use of the Internet, and that research goes through several phases where the first phase is aimed at identifying possible stories and the following phases follow up and expand on story-lines selected.

The survey-based approach to the understanding of the role of the Internet in the journalistic research process may also explain the widespread expectation that the Internet will further strengthen the media's dependency on subsidized contents. Over time a number of researchers have pointed out that the media is heavily dependent on 
information subsidies in the form of press releases, photos, press tours and ready-made contents (Gans 1979, Fishman 1980, Gandy 1982). On the basis of a survey with 101 computer journalists in the US, Hachigan and Hallihan (2003) conclude that the Internet is likely to accelerate this dependency as companies and organisations make more and more information available on websites. Amongst the journalists surveyed there was a strong awareness that research on the Internet could save both time and money for the media organisations.

\section{Adding Value to Information Found on the Internet}

The question is, however, if the media can afford to rely on information mainly obtained by searching the Internet? In favour of the argument is the fact that many journalists experience that they are expected to produce more articles and broadcast items and at the same time they have less resources available in the form of time and money. A Danish survey of 527 journalists from 2001 shows that 43,8 per cent of all respondents feel they are expected to produce more stories than previously whilst 49,7 per cent of the respondents feel that they have fewer resources at their disposal (Nørgaard Kristensen 2004:88). For such journalists the Internet is potentially what makes it possible to close the gap.

Against the argument is the fact that readers, viewers and radio listeners all have the same access to information on the Internet as journalists do. With the Internet, people do not need the media as intermediaries to the same extent as they did earlier. People can choose to find their own information on the Internet and dispense with the media all together. That raises the question if the Internet in reality is capable of saving the media time and money in the research phase. It seems more likely that it is necessary for the media to add value to information found on the Internet in order to have a marketable product.

It is possible to point to three levels of value journalists can add to information found on the Internet. And obviously cost conscious media organisations would spend as few resources as possible in that process.

\section{Minimum added value}

The simplest type of value journalists can add to information found on the Internet is to present it in a journalistic format. That means selecting the most important elements and presenting them in an appropriate genre. It is a service that makes it easier for the audience to understand the information but it does not demand further research on the part of journalists.

\section{Medium added value}

Journalists can add value to information found on the Internet by supplementing it with information that is not available on the net. It could be in the form of background information and building context by adding information from other sources. In the context of reporting about local politics, journalists can also undertake democratic control functions by asking critical questions. Still, the amount of extra research required is moderate as most of the information necessary for background, contextualisation and democratic control can be gathered through (relatively) short interviews on the phone or personal interviews. 


\section{Maximum added value}

The Internet is a cornucopia of information but some of it you have to work very hard on obtaining through specialised searches and analysis of database content (computerassisted reporting). This type of journalism often produces new knowledge and solostories for individual media organisations. That is very valuable - also because audiences rarely have the skills to gather this kind of information themselves. The amount of extra research is considerable, and often the journalist needs special skills and knowledge about research methods to produce good stories.

\section{Research Questions}

The research presented in this article draws on qualitative interviews with nine Danish journalists who specialise in council reporting for provincial newspapers. The journalists have been interviewed about their use of the Internet in the research phase to illuminate these questions: What importance do journalists ascribe to research on the Internet compared to other methods of research, and how do journalists combine research methods? During which phases of the research process is the Internet most helpful? What impact does the Internet have on the relationship between journalists and their oral sources? Does the journalists' awareness that readers, viewers and listeners have the same access to information on the Internet as journalists themselves, impact on the importance of the Internet as a research tool?

The purpose of these questions is two-fold: Firstly, the answers help to draw a more complex picture of the use of the Internet in the journalistic work process and will also show the impact of the Internet on work routines as well as changes in relations with the journalists' other sources of information. Secondly, the answers will help determine how much value journalists feel they need to add to information found on the Internet in order for an article to work as a piece of journalism.

\section{Why Look at Council Reporting?}

Councils are what sociologist Mark Fishman (1980) has labelled a bureaucratic source in his classic study of journalistic research methods. Following reporters at a local newspaper in California, Fishman found out that regardless of the beat journalists get most of their daily information from formal institutions and organisations within the beat. The court reporter calls on instutions like the police and the courts, and the council reporter visits with the many branches of local administration.

The reason is that all of these institutions produce their own bureaucratic records of events and decisions within their jurisdiction that journalists can consult later for story information without having to be physically present when events take place.

This working method is well known not only in the US but also in Great Britain, Sweden and Denmark (Murphy 1978, Nygren 2001, Sparre 2002).

For Danish council reporters the key documents in council reporting are agendas and minutes from committee meetings within the political administration. Through these documents reporters learn about new political and administrative developments and can follow cases through bureaucratic phases to their conclusions.

During the past decade the majority of Danish councils have built their own websites where key bureaucratic documents such as agendas and minutes from council meetings are made available to the public including journalists. So for most council reporters, the 
advent of the Internet is something they have been forced to at least acknowledge as an option for research as opposed to for instance police reporters who will seldom be able to use the Internet for routine stories because the majority of Danish police stations do not post their daily reports on a website (Sparre, 2002).

Considering the similarities in working methods for council reporters across Denmark, it seems fair to assume that there will also be similarities in the ways that reporters have integrated the Internet in their reporting. This makes it a good basis for investigating how important Internet research has become to journalists not only in relation to other methods of research but also compared to other beats and types of reporting where reporters can have a more idiosyncratic approach to their research and use the Internet very differently.

The choice of newspaper journalists as subjects of study is also deliberate. Newspaper journalists are different from radio and television reporters in the sense that the latter in most cases are forced to consider using other approaches to research as they need telephone or face-to-face contact to collect the pictures and soundbites that are indispensible components of storytelling for their media types. Journalists working for print media have a bit more leeway when it comes to quoting. They do not necessarily need an oral source for the story to work and may therefore find the Internet more useful as a source than their colleagues in radio and televison.

\section{Danish Council Reporting in Context}

Before embarking on the analysis of the use of the Internet by Danish council reporters, it is useful to reflect on the historical development of council reporting and its relationship to the emergence of the Internet.

As noted above, the council is a bureaucratic source where key documents to monitor progress of particular political issues are agendas and minutes from meetings in political sub-committees as well as the main council. When Fishman did his research in the 1970 's, journalists often reported on a case when it moved from one bureaucratic phase to the next. However, since then the media has become more professional and less dependent on agendas dictated by the dynamics of political systems at both the national and local level (Hjarvard 1999, Pedersen 2000, Nygren 2001, Lund 2002). Instead of focusing on the minutiae of all political discussions, the media now concentrates on those issues where there is disagreement or even conflicts between politicians and groups of citizens (Nygren, 2001:135). Typically, journalists would like to cover a case as early as possible and at a time where it is still possible to influence political decisionmaking on the matter. So by the time a particular case reaches the final round of decisionmaking in the council, the topic could easily have exhausted its news value. Conversely, journalistic interest in a council matter could start well before it enters the agenda of a political sub-committee if a group of citizens decides to engage the local media in their attempts to gain political support for a new sports venue or different rules for parental choice in the provision of childcare.

Whilst the movement of a case through bureaucratic phases can no longer be used as a script for media coverage, agendas and minutes are still some of the key tools for journalists to monitor local political developments in order to discover potential flashpoints.

Over the past 20 years there has been a gradual development in how journalists have learned about the cases discussed by local politicians. Meetings of the city council have always been public and covered by journalists in person, but 20 years ago it was not 
unusual for a council reporter to only know the date for a meeting in political sub-committees. The journalist would then have to call the chair of the sub-committee to obtain further information about the cases discussed as well as decisions made. During the 1990's this firm political gatekeeping of council news was relaxed as many councils started to make agendas for sub-committee meeting available to the public and the media at the public library or the town hall. Today most councils have a website where agendas and minutes are available for everyone.

Research on how citizens in two Danish municipalities use the council website shows that citizens have discovered and also use the access they have been given to agendas and minutes from political meetings. 31 per cent of citizens participating in one survey said they had looked at agendas and minutes at the council website (Olsen et al., 2004:18) and the same applied to 52 percent of citizens participating in another survey (Hoff and Marckmann, 2004:11).

In other words, local politics has gradually become more transparent and easy to monitor and has now reached a point where journalists and citizens have equal access to basic information, and many citizens do avail themselves of the opportunity to do research on their own.

\section{The Interviews}

The nine council reporters interviewed come from four different local and regional provincial newspapers in Denmark. The journalists were selected at random and each one covers a different council.

The journalists are all professionally trained or have worked as journalists for an average of 13 years that covers variations from three to 22 years of journalistic work experience. Most of them have been council reporters for the duration of their careers and therefore they are also capable of reflecting on how the Internet has changed their own working practices.

The journalists were all interviewed at their work place for 40-60 minutes about

- How they use the council's homepage and other webpages for procuring information and how important Internet research is in relation to other research methods

- Whether the Internet saves time for journalists

- How they use e-mail in their relationship with local politicians and citizens

- How journalists can add value to information from the Internet for an audience that has the same access to information as journalists

The data have a qualitative nature and were intended to explore broad tendencies and complexities. However, it turned out that there was a high degree of agreement between interviewees on a number of aspects and that is why the following description of key findings often refer to "all journalists". That should not be confused with a quantitative approach to the data.

\section{How Council Reporters Use the Internet for Research}

The interviews showed that the Internet has three important research functions for council reporters all of which will be explored in further detail below: 
- The Internet improves the ability of journalists to monitor and identify possible stories from the realm of the council.

- The Internet has made it easier to identify sources and information that can be used to provide perspectives on local political developments, and generally the Internet has made it practically possible to carry out meaningful research outside council borders.

- The Internet provides easier access to factual information about council affairs which journalists previously had to gather by calling council employees or politicians. This impacts on the way journalists relate to their oral sources.

\section{Using the Internet to Monitor Council Affairs}

For most of the journalists interviewed, the council website has become the cornerstone for their work.

The council website serves several purposes: It supplies journalists with factual information about council affairs and identifies potential sources within the administration. It also serves as a long distance searchable archive for council affairs and has to a large extent eliminated the need for journalists to build their own paper archives with copies of old agendas, minutes and attachments. The most important function of the council website, however, is as a surveillance tool that allows journalists to follow developments within the council and detect possible stories by following the accounts that the council generates about its own activities and post on the website.

The most important documents for council reporters are still agendas and minutes from council committees and council meetings. All journalists look them up on the website unless there are alternative and better arrangements in place such as having agendas with attachments sent through the post. In general though it seems that the routine relationship between councils and council reporters has changed and is no longer based on paper but on digital communcation where the journalists actively look for information on the website rather than receiving it through the mail.

Council websites have offered journalists a number of new ways of monitoring council affairs. One is the publication of a daily post list which shows who have sent letters to the council and recipients of letters from the council. Through such lists journalists can detect cases that might not have showed up elsewhere in the system, and journalists who have access to post lists praise them whereas journalists covering councils without post lists miss them:

The council has post lists on its website, and we often find documents there. We look at it often - daily, in fact - to see if something interesting has come up and ask for access to relevant records that way. (Journalist, Nordjyske Medier, Aalborg)

The Internet has also made it possible to monitor particular areas of council activity at quite a detailed level. Previously minutes from for example school board meetings were only sent to participants but now they are often posted on the school's website so that parents can read them. But journalists read them too:

I follow the links from the council website to the website of individual schools. I often read minutes from the school board or messages from the school's administration because that way I sometimes find ideas for a feature. (Journalist, Jydske Vestkysten, Kolding) 
Journalists can be quite creative in using elements on a website for monitoring purposes. A council in Northern Jutland publishes the mayor's weekly schedule on the website, and the local editor monitors it closely:

Depending on the meetings scheduled in the calendar, it is possible to see if there is movement on certain issues. I can call the mayor and ask: "You are going to meet with these people, what are you going to talk about?" Or I can call him afterwards: "You just had a meeting, what did you talk about?" (Local editor, Nordjyske Medier, Hadsund)

\section{Using the Internet to Gain Perspective}

Obviously journalists use many other websites than the council website when researching their stories. Some journalists create search robots that trawl the net continuously for references to a particular council and forward the links to the journalist in an e-mail. A more selective approach is to look for additional information for specific stories by looking up relevant websites or using a search engine.

If the local council is working on a project, I check on Google to see if other councils have made similar projects and what their experiences were. At the moment, the local council is discussing whether to introduce vacuum-packed food and then it is a good idea to see what kind of experiences other councils have had with that. (Journalist, Jydske Vestkysten, Esbjerg)

Generally speaking journalists experience that with the Internet it has become easier to expand on stories with sources and information that does not originate from the council administration or politicians. Journalists feel that it helps improve the quality of their articles:

At the moment we have problems with rats in the area and a kindergarten had to be re-housed. When writing that story I visited the webpage of the Danish Environmental Protection Agency ... I was looking for factual information and I think it is highly relevant to inform people about why rats are dangerous. I also showed how you prevent rat problems at home. (Journalist, Jydske Vestkysten, Varde)

\section{Using the Internet to Lessen Dependency on Local Sources}

The increasing amount of factual information about council affairs available on the Internet has meant that journalists have become less dependent on local sources. That makes it easier to be critical but journalists also believe that it enables them to ask better questions.

More information is accessible. It is easier to establish an overview of what is available instead of having to ask a committee chair or someone from the administration. They might not be very interested in telling you what they have.... The fact that we can get information beforehand really makes a difference in terms of what you can ask about. (Journalist, Nordjyske Medier, Aalborg)

Information gathered on the Internet makes it easier to determine the contents of stories regardless of input from oral sources. Instead of looking for a story in conversations with a source, journalists might now have the whole storyline in place before they ring up for a comment. 
There is probably going to be less personal contact in the future. When you read the minutes, you already have a good idea about the storyline before you call people ... You already know what kind of comments you want. (Journalist, Jydske Vestkysten, Esbjerg)

Conversely, the Internet also establishes a form of base-line in the relationship between journalists and their sources where the journalist feel that it is important to check on the Internet before calling up new sources or sources the journalist does not have a long working relationship with.

As a local editor I sometimes have a story that involves the county. In those cases I use the Internet a lot because I do not know the sources in the same way as I do here. I would never call up a politician from the county without checking on the Internet first. I have to be prepared in a completely different way when I call someone I don't know. If I am not prepared I will lose their trust and respect in the interview. (Local editor, Herning Folkeblad, Aaskov)

\section{Research on the Internet Is Not a Timesaver}

The journalists interviewed all agreed that the Internet has made it easier to find information and sources to contact. Certain tasks can be done quicker but in general none of them feel that access to the Internet has saved them time enough to produce more stories. On the contrary:

If you want to put something into context, the Internet gives you so many new ways of researching. You don't save time because you find so much uncessary information. You are bombared with information and it is difficult to decide to limit yourself. It is hard when you research to tell yourself that now it is enough. Maybe there is something very interesting on the next website you look at. (Journalist, Jydske Vestkysten, Esbjerg)

Some journalists experience that researching on the Internet has come to take up so much time that they feel they are neglecting other important ways of doing research such as visiting people or finding stories by roaming the area and observing what is going on.

\section{The Role of E-mail in Research}

An integral part of the Internet is e-mail that can be used for research purposes as well. All journalists interviewed have e-mail accounts but also unanimously agreed that they do not use e-mail for interviews. They prefer to do interviews on the phone or face-toface because that allows them to follow up answers with new questions and react to nuances in what their sources tell them. However, many journalists use e-mail to establish interviews - particularly with people whom it is difficult to get access to.

On the other hand, e-mail has made it easier for ordinary people to access journalists. Citizens e-mail journalists with all sorts of stories: They tip journalists with story ideas, send letters to the editor and advance publicity for events they are organising. Journalists are happy to publish service information without getting in touch with the sender but if the story is just a little bit controversial, journalists will contact the sender on the phone. Generally the journalists interviewed were happy that e-mail had expanded the timeframe where people could get in touch with them, and they were pleased to note that after the advent of e-mail more ordinary people contact the newspaper. 


\section{The Internet Is Not a Competitor for Audience Attention}

The journalists interviewed experience that the Internet allows them to write qualitatively better stories for their readers. And it is exactly by providing contextualisation and democratic control that journalists believe they create added value for their readers and give them an argument for bying a newspaper instead of locating information on the council website themselves.

None of the journalists interviewed were particularly worried about the fact that their readers have exactly the same access to information on the Internet as they do. Research on the Internet is a time consuming process, and journalists are quite sceptical about the amount of information that readers gather from council websites and how easy it is to make sense of the information.

People are not trained in the same way as us in looking for information and therefore we have an important job in selecting on their behalf. They may only have three minutes to read an article that I have spent four hours researching. So in that sense it doesn't matter that people can see the same things as us on the Internet. (Journalist, Aarhus Stiftstidende, Aarhus)

Instead journalists can add value for readers by directing them from a newspaper article to a council website.

Based on the overview I provide it should be easier for people to go to the council website and find the information they need. Take district planning as an example. With my help they can locate a plan, zoom in on the map and realise: "This is where we live. Help. Somebody is going to build a house over there. (Journalist, Herning Folkeblad, Herning)

So journalists experience that they have a role as guides for their readers on how to use the Internet. On the other hand, the journalists interviewed also welcomed the fact that with the Internet it has become easier for readers to check up on information provided by journalists.

\section{Assessing the Overall Importance of the Internet to Research}

Assessing the overall importance of the Internet to their reseach efforts, all journalists interviewed agreed that information from the Internet is only that. It takes more work to turn that information into journalism. Aside from notes and fact files, all journalists denied that you can write stories based alone on information found in agendas and minutes published on a council website. As a last resort journalists may write up a story without further research but only if he or she already posesses background information to qualify new developments they learn about from the council website.

Generally journalists agreed that information on council websites are not prepared for journalists. Reporters continue to call the mayor and chairs of council committees after and sometimes also before meetings to get background information and political statements.

Journalists make sense of what is on the Internet when it comes to council reporting. A text on a council agenda is aimed at presenting politicians with a basis for decision-making ... It is our job to find out what happened earlier, put it into context and find out what might make politicians vote one way or the other. (Local editor, Nordjyske Medier, Hadsund) 
I could not imagine writing an article based on what I found on the council website and where I just rephrase it a bit. Obviously, we put the information into a wider context to create debate or outline areas of disagreement or conflict. Because it is our job to describe what the story is about whereas the council probably has a natural tendency to describe developments without too many edges. (Journalist, Aarhus Stiftstidende, Aarhus)

In order to provide context, journalists must contact a number of different sources to put names, faces and personal opinions to the story. Journalists give life and meaning to a story by drawing on the opinions of individuals and this kind of information is very unlikely to make it onto the Internet especially in very small communities. However, journalists often get a good idea about whom to contact by searching on the Internet.

It is also important to the journalists interviewed that they are seen to exercise a certain amount of democratic control and several of them pointed out that regardless of the quality of a council website it offers only one side of the story. Journalists should bring out more sides to a story, and they are not necessarily found on the Internet.

\section{Conclusions}

Applied to the continuum of minimum to maximum added value, journalists interviewed emphasized how they add value to information found on the Internet by providing background information, context and quotes. That was labelled medium added value above.

Only rarely do journalists add only the minimum value of presenting information found on the Internet in a journalistic format. Larger projects that were labelled maximum added value above also seem to be rare. In fact, only one journalist interviewed mentioned that he had used the Internet for a large scale survey of a matter of local importance.

Implicit in the answers from journalists is a fundamental belief that it is through the personal efforts of journalists in combining information that journalism is created. Information found on the Internet or gathered through interviews are just basic building blocks. From that point of view it is unlikely that the Internet will save the media time or resources during the research phase.

The question is, however, how far this conclusion is valid. The journalists interviewed all work on a beat where the audience expects them to undertake democratic service functions by providing context to political developments and challenging local politicians by asking critical questions.

On other beats the audience does not have the same expectation of journalists. That applies for instance to advance publicity for events or stories from the police beat where information from the police's daily reports as a rule is relayed uncritically (Sparre 2002:57).

In genres or beats where there already is a tradition for a minimum effort on the part of journalists, the Internet is much more likely to become a tool that will save media organisations time and money in the research phase. This is acknowledged by the journalists interviewed, and several of them called press releases received on mail for a gift because it is easy to cut and paste text into the article.

On the whole this research does not give credence to worries that journalists increasingly find all their information on the Internet. For council reporters there is no technological determinism in having access to the Internet. Instead the Internet is a tool that is used when it is practical or can improve the quality of the finished journalistic product. 
Journalists interviewed did use considerable time researching on the Internet but that does not mean that they have given up on other research methods in part because the usefulness of the Internet for research purposes is limited by the human factor. The journalists emphasized their belief that the audiences want types of information that is not available on the Internet but is a result of journalists going to see places for themselves and talk to people face-to-face in order to probe their feelings and opinions on particular issues. This demand for human presence reduces the Internet to only one of several research tools available to journalists although the Internet may be preferred to a larger or lesser extent depending on tradition and genres in particular beats.

The journalists interviewed all experienced the Internet as a resource and not a competitor for the attention of the audience and that can probably also be explained by the human factor. The Internet does not have the capacity to distill and extract meaning from information or determine when the information needs to be supplemented by other types of information to provide a better picture of reality. That is still a task for humans and so far journalists experience that it is a task that the audience is quite happy to leave with them.

As mentioned in the introduction, there has been very little qualitative research on the way journalists use the Internet for research. This research has proved the usefulness of such an approach but it also raises other questions. Council reporting is by its very nature local, and local media are at the bottom of what Lund has called the news food chain (Lund 1999). In a research project which counted all news produced by national and regional television and radio-stations, the national news agency, and local, regional and national newspapers in Denmark for a week, it turned out that journalists working for local newspapers produced 88 per cent of all original news stories during that week. Journalists working for other media higher in the news food chain often quoted or expanded on stories from local newspapers and therefore relied on research carried out by local journalists. Therefore it is relevant to ask, if journalists working for media higher in the food chain rely more on the Internet for research than for instance council reporters because they rework news stories found on the Internet?

The council reporters interviewed were also part of a fairly well defined political scene where many of them had operated for years and gained detailed knowledge of issues and people involved. But do journalists working on topics and issues that they are not familiar with use the Internet for research in the same way as council reporters? Probably not, but at present very little research looks at how important Internet research is when journalists want to open up stories they have little grounding in beforehand. At what point do journalists in these situations diversify their methods of research and decide to include interviews or personal observation of events? What does journalism look like if reality is primarily represented through information on the Internet rather than personal contact? Does the Internet expand the choice of sources for journalists, and can an Internet presence confer prestige on sources that might have gone unnoticed before the invention of the Internet?

\section{Note}

1. There have been two main approaches to research on how journalists use the Internet for research. One approach looks at the relationship between journalists and commercial companies where pr-companies have undertaken surveys of how journalists like to research on company websites in order to improve the company's Internet communication with journalists. Examples are the big annual Middleberg-Ross Surveys (1996-2003) and a survey from Rainer PR (2003) in Britain. Another approach is surveys of 
how the Internet has been incorporated into newsrooms. Most of this research stems from the period 1994-2000 where the Internet was not as established as it is now. Examples of this approach is an early survey of how Australian journalists use the Internet (Metcalfe and Gasgoigne, no date), a survey from 2000 of how the Internet has been integrated and is viewed by British journalists (Netmedia 2000), and a study from the Institute for Politics, Democracy and the Internet in the US about political journalism on the Internet (May, Graf and Thompson 2002). The American professor Bruce Garrison has also undertaken a number of studies of how the Internet has been integrated and used by journalists in news rooms in the US. (Garrison 2003, 2001, 2000).

\section{References}

Fishman, Mark (1980): Manufacturing the News, University of Texas Press

Gans, H.J (1979): Deciding What's News, New York: Pantheon Books

Gandy Jr., O.H (1982): Beyond Agenda-Setting: Information Subsidies and Public Policy, Norwood, NJ

Garrison, Bruce (2003): "How Newspaper Reporters Use the Web to Gather News" in Newspaper Research Journal, June 22, 2003

Garrison, Bruce (2001): "Newspaper Roles Shape World Wide Web Searches" in Newspaper Research Journal, September 22, 2001

Garrison, Bruce (2000): “Journalists' perceptions of online information-gathering problems" in Journalism \& Mass Communication Quarterly, vol. 77, no. 3, fall 2000, pp. 500-514.

Hachigan, David og Kirk Hallahan (2003): "Perceptions of public relation web sites by computer industry journalists" in Public Relations Review, vol. 29, issue 1, March 2003, pp 43-62

Hjarvard, Stig (1999): TV-nyheder i konkurrence, Copenhagen: Samfundslitteratur

Hoff, Jens and Beela Marckmann (2004): Internet og det lokale demokrati i Odder kommune dokumentation af en spфrgeskemaundersфgelse, Working Paper no. 10, Copenhagen: Center for Media and Democracy in the Network Society

Kristensen, Nete Nørgaard (2004): Journalist og kilder - slinger i valsen?, Aarhus: Forlaget Ajour

Lund, Anker Brink (2002): Den redigerende magt, Aarhus: Aarhus Universitetsforlag

May, Albert, Joseph Graf og Jason Thompson (2002): The Virtual Train: Political Journalism on the Internet, The Institute for Policy, Democracy and the Internet, George Washington University

Murphy, David (1978): "Control without Censorship" in James Curran (ed.): The British Press, a Manifesto, London: Macmillan

Nygren, Gunnar (2001): Medier och medborgare i den digitala kommunen (Media and citizens in the digital council), Stockholm: JMK

Olsen, Leif, Stine Christensen and Olaf Rieper (2004): Borgernes brug af Søllerød kommunes hjemmeside - dokumentation af en spфrgeskemaundersøgelse, Working Paper no. 7, Copenhagen: Center for Media and Democracy in the Network Society

Pedersen, Ove Kaj et al. (2000): Politisk journalistik, Aarhus: Centre for Journalism and Further Education Rainer PR (2003): Developing a Best Practice Online Press Room, A Rainer PR White Paper, www.rainpr.co.uk

Sparre, Kirsten (2002). Politiet som kilde, CFJE-rapport no. 4, Aarhus: Centre for Journalism and Further Education (CFJE)

\section{Surveys Published on the Internet}

Metcalf, Jenni og Toss Gasgoigne (no date): Survey on how Australian Journalists use the Internet, published at http://www.econnect.com.au/pdf/internet_svy.pdf

Middleberg, Don og Steve Ross (1996-2003): Annual Surveys on Media in Cyberspace, pdf-copies of reports from 1996-1999 and abstracts from reports from 2000-2003 are published at http://64.29.206. 70/toolsforsuccess/surveyofmedia.cfm

Netmedia 2000 og City University's Department of Journalism, London (2000): UK Media in Cyberspace Survey 2000, was published at http://www.net-media.co.uk/survey/

KIRSTEN SPARRE, Ph.D., Journalist, External Lecturer at Centre for Corporate Communication, Aarhus School of Business, University of Aarhus, DK-8210 Århus, kirstensparre@gmail.com 